Çukurova Üniversitesi Mühendislik Mimarlık Fakültesi Dergisi, 35(1), ss. 11-18, Mart 2020

Çukurova University Journal of the Faculty of Engineering and Architecture, 35(1), pp. 11-18, March 2020

\title{
Araç Parçalarının MEMS Manyetometre Sensör Çıktısına Etkisi
}

\author{
Murat BAKIRCI ${ }^{* 1}$ \\ ${ }^{1}$ Tarsus Üniversitesi, Havacılık ve Uzay Bilimleri Fakültesi, Havacılık ve Uzay \\ Mühendisliği Bölümü, Tarsus
}

$\ddot{\mathbf{O z}}$

Geliş tarihi: 11.11.2019 Kabul tarihi: 15.05.2020

Birçok Akıllı Ulaşım Sistemi (AUS) için araçların yön bilgisinin hassasiyeti oldukça önemlidir. GPStabanlı konumlandırma ve yön tahmini neredeyse bütün ulaşım sistemlerinde yaygın olarak kullanılmaktadır. Fakat şehir merkezlerindeki çevresel etmenler nedeniyle GPS sinyali algılamasında tutarsızlıklar meydana gelmektedir. Mobil cihazlarda bulunan jiroskop, ivme ölçer, manyetometre gibi Mikroelektromekaniksel Sistem (MEMS) sensörleri, taşıt dinamiği ölçümlerinde oldukça güçlü bir potansiyele sahip olmak ile birlikte taşıtlarda yön tahmini ile ilgili çalışmalar yapabilmek için de oldukça elverişlidir. Akıllı mobil cihazlardaki manyetometre sensörleri, hassas yön tahmini yapabilmek için kullanışlı duruma getirilebilirler. Fakat manyetometre sensörü tarafından ölçülen manyetik alan verisi, taşıtın ferromanyetik parçaları nedeni ile ciddi şekilde deforme olmaktadır. Bu çalışmada, hata parametreleri saptanarak hassas olarak taşıt yön tahmininin nümerik olarak elde edilebileceği ortaya konmuştur. Hata parametreleri matematiksel bir modele dönüştürülerek etki eden hatalar ham sensör verisinden elimine edilmiştir. Simülasyon sonuçlarına göre modelin ürettiği maksimum hata \%3.4’tür.

Anahtar Kelimeler: Taşıt yön tahmini, Manyetometre, Ferromanyetik nesne, MEMS sensör, Akıllı ulaşım sistemleri

\section{Effect of the Components of a Vehicle on a MEMS Magnetometer Sensor Output}

\begin{abstract}
Precise vehicle heading information is of great importance for many Intelligent Transportation Systems (ITS) applications. GPS-based localization and heading estimation is widely used in almost every transportation systems. However, dense urban environment causes inconsistency in the reception of the GPS signals. Given the diverse sensors within mobile devices, i.e., Microelectromechanical System (MEMS) sensors such as gyroscope, accelerometer, magnetometer etc., they have a strong potential for sensing vehicle dynamics and can promote a broad range of applications associated with heading estimation. A magnetometer sensor of a smart mobile device can be utilized to obtain accurate vehicle heading estimation. However, ferromagnetic components of a vehicle significantly deforms the magnetic field measured by magnetometer sensor. In this study, it is demonstrated that an accurate vehicle heading estimation can numerically be achieved through identifying error parameters. These parameters were then transformed into a mathematical model and contributing errors were eliminated from raw sensor output. Simulation results show that the model produces a maximum error of $3.4 \%$.
\end{abstract}

Keywords: Vehicle heading estimation, Magnetometer, Ferromagnetic object, MEMS sensor, Intelligent transportation systems

*Sorumlu yazar (Corresponding author): Murat BAKIRCI, muratbakirci@tarsus.edu.tr 


\section{INTRODUCTION}

There are variety of techniques available to collect and analyze vehicle data in Intelligent Transportation Systems (ITS) perspective. Traditional data collection techniques have some prominent disadvantages such as high installation and maintenance cost [1]. On the other hand, modern smart mobile devices, which embedded with Micro-electro-mechanical system (MEMS)based low cost Inertial Measurement Unit (IMU) sensors such as accelerometer, magnetometer and gyroscope, have powerful computing and sensing capabilities. Using these devices in ITS applications have relatively eased the process of dynamic travel data and vehicle data collection.

Due to their significant contributions to the applications in various fields, such as industrial, aerospace, automotive, military, the usage of magnetometer sensors is exponentially increasing. A MEMS magnetometer can facilitate constant and high navigation data rates which put forward itself as a key component for a wide range of applications. The primary reason to develop these sensors was to utilize them for navigation purposes only. Accurate heading measurement of a vehicle is one of the most important parameter for many ITS applications such as automatic guidance and control [2]. In this context, a MEMS magnetometer sensor have become quite popular for the navigation of ground vehicles.

Magnetometer sensors can utilize the Earth's magnetic field as a bias field for detecting the presence of ferromagnetic objects. However, the magnetic flux generated by the ferromagnetic components of a vehicle remarkably deforms the Earth's magnetic field around the vehicle [3-5]. Moreover, certain type of components may also produce a permanent magnetization effect.

In the literature, various techniques have been reported for the calibration of magnetometer sensors in the magnetic field domain [6-8]. This study utilizes a magnetometer sensor by identifying error parameters which affect the sensor readings. Factors that influence magnetic field in a vehicle such as, car body shell and power cables, were transformed into a mathematical representation, so that, contributing errors can be eliminated from raw sensor readings.

\section{PROBLEM OVERVIEW AND THE METHODOLOGY}

A MEMS magnetometer sensor simply measures the strength and direction of the local magnetic field. The magnetic field measured will be a combination of both the Earth's magnetic field and magnetic field created by nearby objects $[9,10]$. Most magnetometer sensors are sensitive to magnetic field less than $10 \mathrm{nT}$ within a $\mp 200 \mu \mathrm{T}$ range. This sensitivity can be compared to the Earth's magnetic field which is roughly $60 \mu T$.

Magnetometer sensors can utilize the Earth's magnetic field as a bias field for detecting the presence of ferromagnetic objects. The magnetic flux generated by the ferromagnetic components of a vehicle remarkably deforms the Earth's magnetic field around the vehicle [3-5]. Moreover, certain type of components may also produce a permanent magnetization effect. Most of the magnetic flux emanate from vehicle is generated by the large components such as engine, axles, driveshaft, among others. The body shell of a typical car also have a significant influence on the magnetic field $[3,11-14]$. An illustration of the behavior of the Earth magnetic field around a typical vehicle is shown in Figure 1.

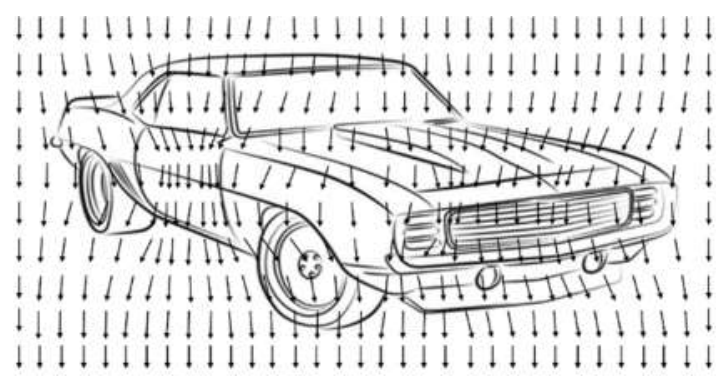

Figure 1. An illustration of the deformation of the Earth's magnetic field around a vehicle 
As mentioned earlier, external magnetic influences cause distortional effects on the magnetic field of the Earth. These magnetic influences can be considered under two aspects: Hard iron and soft iron effects. In case of absence of distortion effects, a circle plot centered around origin is obtained from the resulting data (y-axis w.r.t. $\mathrm{x}$ axis) while having a magnetometer rotated through a circle as shown in Figure 2 (a).

However, a hard iron effect for instance, produces a fixed amount of magnetic disturbance on the existing magnetic field, thus, results a certain amount of offset in the $\mathrm{x}$ or $\mathrm{y}$ direction. Therefore, the center of the circle plot no longer locates at the origin. On the other hand, the soft iron effect causes a deformation in the circle plot which results an ellipse. It is also likely that both effects will contribute to the total distortion simultaneously. The simultaneous compensation of both distortions will also be dependent on the motions of the distorting materials relative to the sensor. Thus, it is important to understand not only how compensation may be applied, but also to recognize those conditions under which effective compensation techniques are not possible.

Hard iron distortion, which caused by magnetized materials, generates a constant additive field to the magnetic field of the Earth. This additive field creates a constant offset from the origin of the magnetic field and it is independent from the position and orientation of the sensing platform. For instance, a speaker magnet induces a hard iron distortion. As long as the orientation and position of the magnet relative to the sensor is constant the field and associated offsets will also be constant. A hard-iron distortion can be visibly identified by an offset of the origin of the ideal circle from $(0,0)$, as shown in Figure 2 (b).

The hard iron effect can be eliminated from the sensor data through determination of $\mathrm{x}$-axis and $\mathrm{y}$ axis offsets and then subtracting from the raw sensor data. Prior to this process, tilt compensation must be applied if necessary. Hard-iron corrections are typically determined by rotating the sensor through a minimum of $360^{\circ}$, then determining the distance from $(0,0)$ to the center of the circle by identifying the average of the maximum and minimum values for each of the axes, as shown in Eq. (1).

$a=\frac{\left(x_{\max }+x_{\min }\right)}{2}, b=\frac{\left(y_{\max }+y_{\min }\right)}{2}$

where $a$ and $b$ are $\mathrm{X}$-axis and $\mathrm{Y}$-axis offsets respectively. Once these constant offset values are computed, they can be eliminated from the raw magnetometer data.

Materials which effect an existing magnetic field but do not induce a magnetic field themselves, cause the soft iron distortion. Different from the hard iron distortion, the soft iron distortion is not additive. Materials such as iron, and nickel induce soft iron distortion. In contrast to hard iron distortion, the amount of distortion produced by soft iron materials is significantly depend on the orientation of the material relative to the sensor and the magnetic field. Therefore, it cannot be eliminated from the raw data with a simple constant. Figure 2 (c) illustrates the deformation in the ideal data caused by the soft iron distortion.

Compensating for soft iron distortion is computationally more intensive than compensating for hard iron distortion. Furthermore, it might be more effective from a cost and efficiency perspective to eliminate the soft iron materials from the proximity of the sensor.

It is first assumed that either the sensor is not tilted and there is no magnetic material to cause hard iron distortion or these two effects have already been eliminated. But if otherwise, the elimination of these distortions must be made prior to soft iron correction. At that point, it is logical to assume that the center of the ellipse is at origin as shown in Figure 26.

Identifying $\theta$ in Figure 2 (d) is accomplished by using Eq. (2) to calculate the magnitude of the line segment $a$, followed by Eq. (3) to determine $\theta$ : 

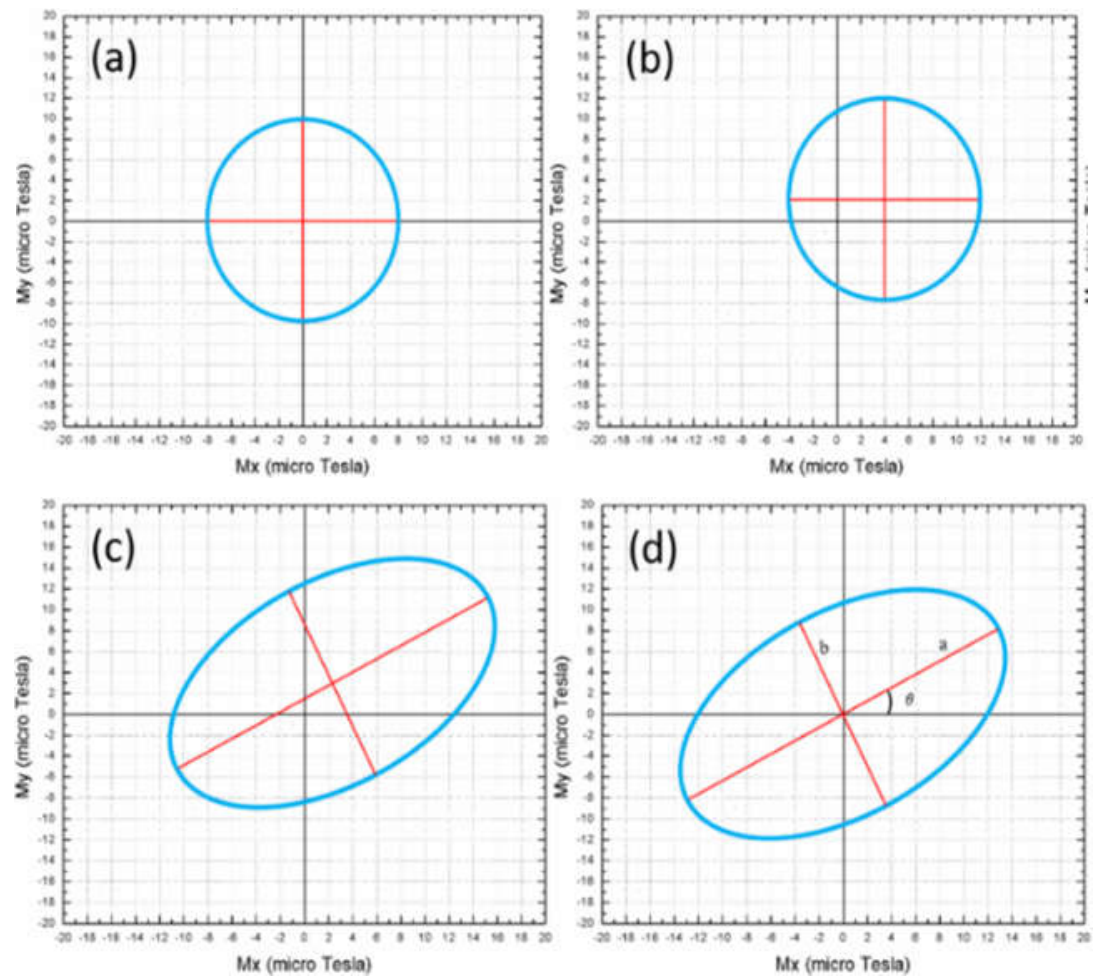

Figure 2. A graph of ideal distortion-free magnetometer data (a); magnetometer data displaying hardiron distortion (b); soft iron effect distorting the ideal circle into an elliptical shape (c); an ellipse generated as a result of soft iron distortion, centered at $(0,0)$ with a rotation angle of $\theta$

$\mathrm{a}=\sqrt{\left(\mathrm{x}_{1}\right)^{2}+\left(\mathrm{y}_{1}\right)^{2}}$

$\theta=\arcsin \left(\frac{\mathrm{y}_{1}}{\mathrm{a}}\right)$

Next, the following rotation matrix is applied to the $\mathrm{x}$ and $\mathrm{y}$ components of the raw sensor values to rotate the ellipse. At that point, the major and minor axes of the ellipse will be aligned with the coordinate frame.

$\mathrm{R}=\left[\begin{array}{cc}\cos \theta & \sin \theta \\ -\sin \theta & \cos \theta\end{array}\right]$

$\mathrm{v}_{1}=\mathrm{Rv}$

It is now possible to scale the major axis such that the ellipse is converted to an approximate circle. The scale factor, $\sigma$, is determined using Eq. (6), $\sigma=\frac{b}{a}$

Since all sensor readings suffer from internal and/or external parameters, it is quite necessary to transform these parameters into a mathematical model so that contributing errors can be eliminated from raw sensor readings through this model. A raw magnetometer sensor reading consists of two type of error sources which are instrumentation errors and magnetic distortion. Sensor sensitivity, bias, and misalignment can be considered as instrumentation errors. Other magnetic influences such as hard iron and soft iron effects can be categorized into magnetic distortion errors.

Considering these magnetic distortions and instrumentation errors along with a fixed noise, $\gamma$, the complete linear mathematical model for a magnetometer sensor can be expressed as [8]: 


$$
\left[\begin{array}{c}
\mathrm{h}_{\mathrm{t}_{\mathrm{x}}} \\
\mathrm{h}_{\mathrm{t}_{\mathrm{y}}} \\
\mathrm{h}_{\mathrm{t}_{\mathrm{z}}}
\end{array}\right]=\left[\begin{array}{ccc}
1 & -\mathrm{m}_{\mathrm{z}} & \mathrm{m}_{\mathrm{y}} \\
\mathrm{m}_{\mathrm{z}} & 1 & -\mathrm{m}_{\mathrm{x}} \\
-\mathrm{m}_{\mathrm{y}} & \mathrm{m}_{\mathrm{x}} & 1
\end{array}\right]\left[\begin{array}{ccc}
\frac{1}{\mathrm{~s}_{\mathrm{xx}}} & 0 & 0 \\
0 & \frac{1}{\mathrm{~s}_{\mathrm{yy}}} & 0 \\
0 & 0 & \frac{1}{\mathrm{~s}_{\mathrm{zz}}}
\end{array}\right]
$$
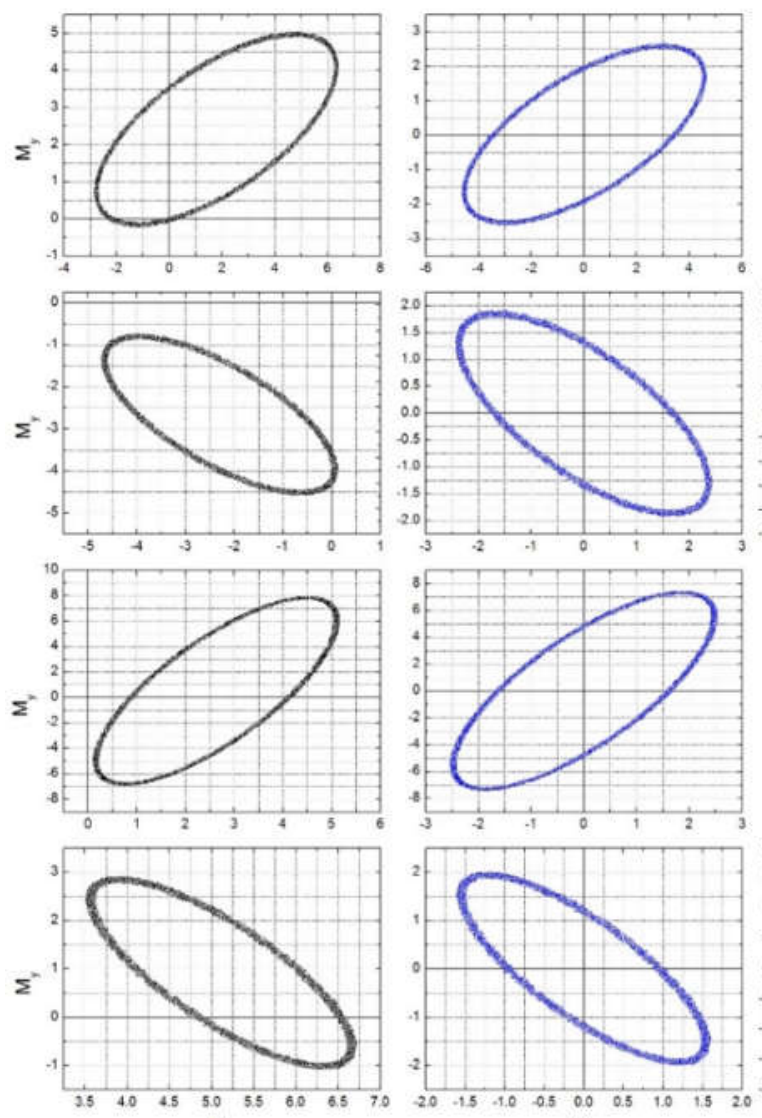

$\mathrm{M}$,

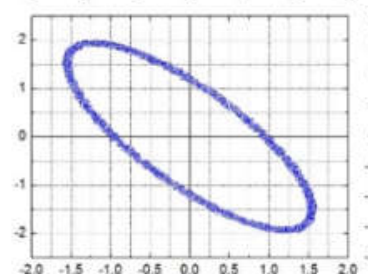

$\mathrm{M}_{\mathrm{x}}$ $\times\left[\begin{array}{ccc}\mathrm{d}_{\mathrm{xx}} & \mathrm{d}_{\mathrm{xy}} & \mathrm{d}_{\mathrm{xz}} \\ \mathrm{d}_{\mathrm{yx}} & \mathrm{d}_{\mathrm{yy}} & \mathrm{d}_{\mathrm{yz}} \\ \mathrm{d}_{\mathrm{zx}} & \mathrm{d}_{\mathrm{zy}} & \mathrm{d}_{\mathrm{zz}}\end{array}\right] \times\left(\left[\begin{array}{c}\mathrm{h}_{\mathrm{m}_{\mathrm{x}}} \\ \mathrm{h}_{\mathrm{m}_{\mathrm{y}}} \\ \mathrm{h}_{\mathrm{m}_{\mathrm{z}}}\end{array}\right]+\left[\begin{array}{c}\mathrm{b}_{\mathrm{x}} \\ \mathrm{b}_{\mathrm{y}} \\ \mathrm{b}_{\mathrm{z}}\end{array}\right]+\left[\begin{array}{c}\mathrm{d}_{\mathrm{hi}_{\mathrm{x}}} \\ \mathrm{d}_{\mathrm{hi}_{\mathrm{y}}} \\ \mathrm{d}_{\mathrm{hi}_{\mathrm{z}}}\end{array}\right]\right)+\gamma$

where $m_{i}, s_{i j}$, and $d_{i j}$ represents misalignment, sensitivity, and soft iron correction matrices respectively. $b_{i}$ and $\gamma$ indicates bias and sensor noise respectively.
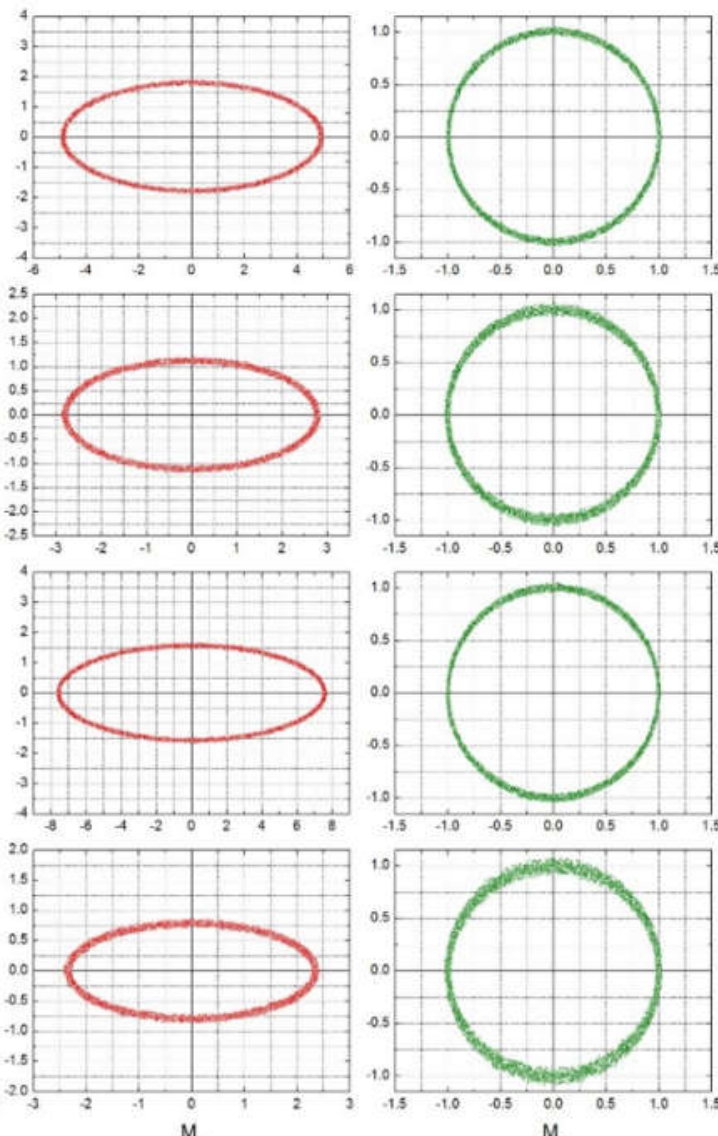

$\mathrm{M}$,

Figure 3. Results of four Monte Carlo simulations for various error parameters. Each row represents one simulation case and each column displays simulation steps

This expression defines the relationship between the true magnetic components, in other words Earth magnetic field components, $\mathrm{h}_{\mathrm{t}_{\mathrm{x}}}, \mathrm{h}_{\mathrm{t}_{\mathrm{y}}}, \mathrm{h}_{\mathrm{t}_{\mathrm{z}}}$ and the raw magnetic sensor measurements $\mathrm{h}_{\mathrm{m}_{\mathrm{x}}}, \mathrm{h}_{\mathrm{m}_{\mathrm{y}}}, \mathrm{h}_{\mathrm{m}_{\mathrm{z}}}$. Considering a two-dimensional drive, the twodimensional form of the Eq. (7) has been used in the simulations.

\section{IMPLEMENTATION OF THE MODEL}

The performance of the magnetometer sensor model above, is tested through Monte Carlo simulation. In order to visualize the modification steps, three sets of error parameters were produced randomly and were 
applied to the data which assumed to be the raw sensor readings. The results of four Monte Carlo simulations using $3.6 \cdot 10^{3}$ sensor readings are plotted in Figure 3. In the figure, each row represents one set of simulation while columns display modification steps where first column depicts raw sensor readings. The misalignment error is neglected for this particular set of simulation since it requires a rigorous coordinate transformation and PCA analysis procedures which are out of the main concept of this study. In the second column, the ellipsoids obtained from raw sensor readings, are translated to the origin, thus, bias and hard iron effects are eliminated. Next, the ellipsoids are rotated along the z-axis by applying the soft iron matrix. Therefore the axes of ellipsoids are aligned with the coordinate axes which means that the soft iron effect is partially removed. Finally, applying the scale factor to the aligned data, the ellipses are converted into approximate circles as shown in the last column.

In the second part of the simulation, only one set of error parameter is produced. The results of fifteen Monte Carlo simulation using $3.6 \cdot 10^{3}$ sensor readings are presented in Table 1 . The average bias estimation errors for $\mathrm{x}$ and $\mathrm{y}$ components of the magnetometer readings are $1.375 \mu \mathrm{T}$ and $1.157 \mu \mathrm{T}$ respectively while the maximum bias estimation error is $1.785 \mu \mathrm{T}$. Considering the total sensor range, $60 \mu \mathrm{T}$, these values indicate the total bias estimation errors for $\mathrm{x}$ and $\mathrm{y}$ components are $2.3 \%$ and $1.9 \%$ respectively. The average scaling and soft iron estimation errors for $\mathrm{x}$ and $\mathrm{y}$ components of the magnetometer readings are $2.072 \mu \mathrm{T}$ and $2.002 \mu \mathrm{T}$ respectively while the maximum error is $2.563 \mu \mathrm{T}$. Similarly, the total scaling and soft iron errors for $\mathrm{x}$ and y components are $3.4 \%$ and $3.3 \%$ respectively.

Table 1. Model estimation errors

\begin{tabular}{|c|c|c|c|}
\hline Simulation No. & $\begin{array}{c}\text { Bias Est. Error } \\
\text { (Micro Tesla) }\end{array}$ & & $\begin{array}{l}\text { Scale/Soft Iron Est. } \\
\text { Error (Micro Tesla) }\end{array}$ \\
\hline \multirow[t]{2}{*}{ I } & $\delta\left(b+d_{h i}\right)_{X}$ & 1.369 & $\delta\left(s+d_{s i}\right)_{X} 1.983$ \\
\hline & $\delta\left(b+d_{h i}\right)_{Y}$ & 1.018 & $\delta\left(s+d_{s i}\right)_{Y} 1.916$ \\
\hline \multirow[t]{2}{*}{ II } & $\delta\left(b+d_{h i}\right)_{X}$ & 0.978 & $\delta\left(s+d_{s i}\right)_{X} 1.796$ \\
\hline & $\delta\left(b+d_{h i}\right)_{Y}$ & 1.254 & $\delta\left(s+d_{s i}\right)_{Y} 2.372$ \\
\hline \multirow[t]{2}{*}{ III } & $\delta\left(b+d_{h i}\right)_{X}$ & 1.695 & $\delta\left(s+d_{s i}\right)_{X} 1.782$ \\
\hline & $\delta\left(b+d_{h i}\right)_{Y}$ & 1.027 & $\delta\left(s+d_{s i}\right)_{Y} 2.269$ \\
\hline \multirow[t]{2}{*}{ IV } & $\delta\left(b+d_{h i}\right)_{X}$ & 0.877 & $\delta\left(s+d_{s i}\right)_{X} 1.912$ \\
\hline & $\delta\left(b+d_{h i}\right)_{Y}$ & 0.959 & $\delta\left(s+d_{s i}\right)_{Y} 1.767$ \\
\hline \multirow[t]{2}{*}{ V } & $\delta\left(b+d_{h i}\right)_{X}$ & 1.528 & $\delta\left(s+d_{s i}\right)_{X} 2.296$ \\
\hline & $\delta\left(b+d_{h i}\right)_{Y}$ & 1.475 & $\delta\left(s+d_{s i}\right)_{Y} 1.807$ \\
\hline \multirow[t]{2}{*}{ VI } & $\delta\left(b+d_{h i}\right)_{X}$ & 1.785 & $\delta\left(s+d_{s i}\right)_{X} 1.873$ \\
\hline & $\delta\left(b+d_{h i}\right)_{Y}$ & 1.581 & $\delta\left(s+d_{s i}\right)_{Y} 1.603$ \\
\hline \multirow[t]{2}{*}{ VII } & $\delta\left(b+d_{h i}\right)_{X}$ & 1.336 & $\delta\left(s+d_{s i}\right)_{X} 1.941$ \\
\hline & $\delta\left(b+d_{h i}\right)_{Y}$ & 0.823 & $\delta\left(s+d_{s i}\right)_{Y} 1.652$ \\
\hline \multirow[t]{2}{*}{ VIII } & $\delta\left(b+d_{h i}\right)_{X}$ & 0.978 & $\delta\left(s+d_{s i}\right)_{X} 2.169$ \\
\hline & $\delta\left(b+d_{h i}\right)_{Y}$ & 1.508 & $\delta\left(s+d_{s i}\right)_{Y} 1.883$ \\
\hline \multirow[t]{2}{*}{ IX } & $\delta\left(b+d_{h i}\right)_{X}$ & 1.562 & $\delta\left(s+d_{s i}\right)_{X} 1.776$ \\
\hline & $\delta\left(b+d_{h i}\right)_{Y}$ & 1.537 & $\delta\left(s+d_{s i}\right)_{Y} 1.969$ \\
\hline \multirow[t]{2}{*}{$\mathbf{X}$} & $\delta\left(b+d_{h i}\right)_{X}$ & 1.335 & $\delta\left(s+d_{s i}\right)_{X} 2.321$ \\
\hline & $\delta\left(b+d_{h i}\right)_{Y}$ & 0.927 & $\delta\left(s+d_{s i}\right)_{Y} 2.425$ \\
\hline \multirow[t]{2}{*}{ XI } & $\delta\left(b+d_{h i}\right)_{X}$ & 1.446 & $\delta\left(s+d_{s i}\right)_{X} 2.271$ \\
\hline & $\delta\left(b+d_{h i}\right)_{Y}$ & 0.918 & $\delta\left(s+d_{s i}\right)_{Y} 2.455$ \\
\hline XII & $\delta\left(b+d_{h i}\right)_{X}$ & 1.533 & $\delta\left(s+d_{s i}\right)_{X} 2.433$ \\
\hline
\end{tabular}




\begin{tabular}{|c|c|c|c|}
\hline & $\delta\left(b+d_{h i}\right)_{Y}$ & 1.252 & $\delta\left(s+d_{s i}\right)_{Y} 2.420$ \\
\hline \multirow[t]{2}{*}{ XIII } & $\delta\left(b+d_{h i}\right)_{X}$ & 1.497 & $\delta\left(s+d_{s i}\right)_{X} 2.563$ \\
\hline & $\delta\left(b+d_{h i}\right)_{Y}$ & 1.201 & $\delta\left(s+d_{s i}\right)_{Y} 1.810$ \\
\hline \multirow[t]{2}{*}{ XIV } & $\delta\left(b+d_{h i}\right)_{X}$ & 1.735 & $\delta\left(s+d_{s i}\right)_{X} 2.026$ \\
\hline & $\delta\left(b+d_{h i}\right)_{Y}$ & 1.024 & $\delta\left(s+d_{s i}\right)_{Y} 2.054$ \\
\hline \multirow[t]{2}{*}{ XV } & $\delta\left(b+d_{h i}\right)_{X}$ & 0.971 & $\delta\left(s+d_{s i}\right)_{X} 1.944$ \\
\hline & $\delta\left(b+d_{h i}\right)_{Y}$ & 0.855 & $\delta\left(s+d_{s i}\right)_{Y} 1.625$ \\
\hline
\end{tabular}

\section{CONCLUSIONS}

Accurate heading estimation is an essential parameter for many ITS applications such as automatic guidance and control, and collaborative autonomous systems. The usage of MEMS magnetometer sensors is significantly increasing in variety of transportation applications due to their technical advantages over conventional sensors. Nevertheless, magnetometer sensor readings are suffered by ferromagnetic materials which generate a magnetic flux. This is indeed relatively lowers the quality of sensor output and makes accurate heading estimation impossible. In this work, error parameters such as, measurement noise and magnetic interference among others, were identified and transformed into a mathematical model, so that, contributing errors were eliminated from raw sensor readings. The performance of the magnetometer sensor model was tested via several Monte Carlo simulations. It is shown that a maximum of $2.563 \mu \mathrm{T}$ which corresponds to less than $4 \%$ heading estimation error was obtained through the simulations.

\section{REFERENCES}

1. Abeygunawardana, T.D., 2014. Smart Data Collection Using Mobile Devices to Improve Transportation Systems, Dissertation, University of Nevada.

2. Kim, Y.C., Yun, K.H., Min, K.D., 2014. Automatic Guidance Control of An Articulated All-wheel-streed Vehicle, Vehicle System Dynamics, 52, 456-474.

3. Jackson, J.D., 1975. Introduction, Boundary Value Problems, Multipoles, Magnetostatics, Maxwell's Equations, $1^{\text {st }}$ ed. NY, John Wiley \& Sons, Inc., ch. 1-6.

4. Moron, C., Cabrera, C., Moron, A., Garcia, A.,
Gonzales, M., 2015. Magnetic Sensors Based on Amorphous Ferromagnetic Materials: A Review, Sensors, 15, 28340-28366.

5. Kahler, G.R., Torre, E.D., Vajda, F., 1992. Static Magnetic Field Deformation by a Ferromagnetic Body, IEEE Transactions on Magnetics, 28, 2274-2276.

6. Egziabher, D.G., Elkaim, G.H., Powell, J.D., Parkinson, B.W., 2006. Calibration of Strapdown Magnetometers in Magnetic Field Domain, Journal of Aerospace Engineering, 19, 87-102.

7. Foster, C.C., Elkaim, G.H., 2008. Extension of a Two-Step Calibration Methodology to Include Nonorthogonal Sensor Axes, IEEE Transactions on Aerospace and Electronic Systems, 44(3), 1070-1078.

8. Renaudin, V., Afzal, M.H., Lachapelle, G., 2010. Complete Triaxis Magnetometer Calibration in the Magnetic Domain, Journal of Sensors, 21, 1-10.

9. Solzbach, U., Wollschlager, H., Zeiher, A., Just, H., 1988. Optical Distortion Due to Geomagnetism in Quantitative Angiography, Proceedings of Computers in Cardiology, Washington, DC.

10. Macmillan, S., Ryeroft, M.J., 2010. The Earth's Magnetic Field, National Env. Res. Council, Online Encyclopedia of Aerospace Engineering, John Wiley \& Sons, Inc.

11. Kittel, C., 2004. "Ferromagnetism and Antiferromagnetism" An Introduction to Solid State Physics, $8^{\text {th }}$ ed. NY, John Wiley \& Sons, Inc.

12. Low, L., Riddle, A., 2012. Simulation of the Effects of Vehicle Bodyshell on Low Frequency Magnetic Fields due to High Voltage Power Cables in Electric Vehicles, IEEE International Symposium on Electromagnetic Compatibility, Rome, Italy.

13. Wolff, J., Heuer, T., Gao, H., Weinmann, M., 
Voit, S., Hartmann, U., 2006. Parking Monitor System Based on Magnetic Field Sensors, Proceedings of the IEEE Intelligent Transportation Systems Conference, Toronto, Canada.

14. Markevicius, V., Navikas, D., Zilys, M., Andriukaitis, D., Valinevicius, A., Cepenas, M., 2016. Dynamic vehicle detection via the use of magnetic field sensors, Sensors, 16, 1-9. 